\title{
The response of the seagrass Halodule wrightii Ascherson to environmental
}

\author{
stressors \\ Chiara M. Bertelli ${ }^{1 *}$, Joel C. Creed ${ }^{2}$, Hanna K. Nuuttila ${ }^{1}$, Richard K. F. Unsworth ${ }^{1}$ \\ ${ }^{1}$ Swansea University. \\ ${ }^{2}$ Universidade do Estado do Rio de Janeiro.
}

\section{Abstract}

Seagrasses are subjected to intense levels of anthropogenic disturbance as a result of the shallow nearshore waters they inhabit. Some seagrasses are known to have dynamic growth patterns, enabling them to colonize unstable shallow environments and adapt to a range of disturbances. This can result in high levels of variability in morphological and physiological attributes. The seagrass Halodule wrightii is known to be a fast-growing pioneering species with a large geographic range. The present study examines Halodule wrightii in a region under intense anthropogenic stress in order to determine what are the main environmental drivers affecting the morphology, physiology and status of these habitats. Parameters of plant morphology, physiology and status were measured either at the meadow scale (e.g. biochemistry) or at a higher frequency shoot scale (e.g. shoot width). We assigned an impact assessment index to a series of seagrass sites over a gradient of anthropogenic disturbance and found this to be explanatory of a number of the seagrass parameters measured including epiphyte cover, stable isotope $\delta^{15} \mathrm{~N}$ and ETR $R_{\max }$ however, it did not clearly explain shoot density, a commonly used bioindicator of environmental stress. At the shoot scale, Principal Component Analysis identified epiphyte and leaf width to have the strongest association. At the meadow scale this was shoot density, dry weight and $E_{k}$, albeit with the most impacted sites showing highest shoot density. Stable isotope $\left(\delta^{15} \mathrm{~N}\right)$ and leaf length were most significant in explaining the variation between sites and impact category, providing a direct link between anthropogenic sources of nutrients to seagrass meadow density. 
Key words: Seagrass; Halodule wrightii; stressors; shoot density; stable isotopes.

\section{Introduction}

The coastal and estuarine waters where seagrasses grow are some of the most heavily impacted regions of the marine environment (Cabaço et al., 2008a; Short and Wyllie-Echeverria, 1996). The anthropogenic pressures from urban and industrial developments occurring in proximity to these areas has resulted in Worldwide declines of seagrass meadows (Short and Wyllie-Echeverria, 1996; Waycott et al., 2009). The biggest threat to seagrasses from coastal development is attributed to poor water quality resulting in the direct or indirect reduction of light availability (Biber et al., 2009; Burkholder et al., 2007; Duarte, 2002; Hemminga, 1998; Jiang et al., 2013). However, in some locations the direct physical damage and removal of seagrass from port/harbour developments and boat anchoring could arguably pose the most critical risk (Grech et al., 2012, 2011).

Seagrasses will exhibit various changes in morphology and physiology in order to adapt to changes in light environment and numerous shading studies have shown decreases in leaf length, leaf width, leaves per shoot and shoot growth (Bertelli and Unsworth, 2018; Biber et al., 2009; Collier et al., 2012; Olesen and Sand-jensen, 1993; Yaakub et al., 2013). The reduction in above-ground biomass reduces respiratory demand of the plant but decreases its photosynthetic capacity and carbon uptake (Campbell and Miller, 2002; Collier et al., 2012; Ralph et al., 2007). Light reduction is rapidly reflected in the photosynthetic performance of seagrasses resulting in a decrease in electron transport rates and carbon capture which can be measured in situ using chlorophyll fluorescence (Bité et al., 2007; Ralph and Gademann, 2005). Events which frequently reduce light to levels below the minimum light requirement (MLR) can lead to plant mortality and meadow die-off. Responses have been found to be species-specific in some cases (Bité et al., 2007; Collier et al., 2016; Silva et al., 2013) with factors such as seagrass plant size (Roca et al., 2016), life history, habitat and meadow form found to be significant in response time and sensitivity to environmental stressors (Kilminster et al., 2015). The 
morphological and physiological changes exhibited by seagrasses in response to changes in light availability make seagrasses good ecological indicators of water quality (Grice et al., 1996; McMahon et al., 2013). However, our knowledge of these seagrass responses to water quality is limited to certain species and localities (McMahon et al., 2013). Nutrient availability is exhibited by the long-term uptake within seagrass tissue, and the ratio of leaf nutrients $(\mathrm{C}: \mathrm{N}: \mathrm{P})$ has been successfully shown to be an indicator of nutrient enrichment in some seagrass species (Burkholder et al., 2007; Carruthers et al., 2005; Fourqurean et al., 1997; Orth et al., 2006). Nutrient inputs can lead to increases in productivity where waters are oligotrophic, but continued nutrient loading has also been found to reduce shoot density (Carruthers et al., 2005; Fourqurean et al., 2003, 1995; Tomasko et al., 1996). The evidence of reduction in shoot density and biomass from nutrient loading highlights the importance of recognising sources of nutrient inputs in seagrass meadows to allow for the management of these habitats for health and resilience. The use of stable isotopes of nitrogen $\left(\delta^{15} \mathrm{~N}\right)$ and carbon $\left(\delta^{13} \mathrm{C}\right)$ are being increasingly used as environmental tracers within marine ecosystems (Jennings et al., 1997; Lepoint et al., 2004), and have been used to provide insight into the sources of nutrients in seagrass meadows (Carruthers et al., 2005; Fourqurean et al., 1997; Jones et al., 2018; Lepoint et al., 2004).

Halodule wrightii (Ascherson) is a common shallow and intertidal seagrass in the Tropical Atlantic Bioregion with its southern limit occurring in Brazil. Populations near the southern limit have rarely been recorded reproducing sexually, making them somewhat borderline and spatially discrete (Creed, 1997). H. wrightii beds have been found to show large amounts of inter-population variation in morphology as well as shoot density and biomass (Creed, 1997). This suggests environmental factors are affecting the morphology and the development or expansion of these seagrasses. Factors such as high sediment instability, low temperatures, strong wave action at low tides or exposure to air have been described as some of the potential factors that limit the existence of $H$. wrightii (Barros et al., 2013), although such drivers remain poorly explored (Creed, 1997; Creed and Amado Filho, 1999; Pitanga et al., 2012). Direct observations of environmental effects on Brazilian seagrasses are limited 
(Barros et al., 2013), with data such as leaf nutrient content and photophysiological attributes lacking in the literature. Decline and die-off of $H$. wrightii meadows have also been attributed to anchor damage and overgrowth of epiphytic algae (Creed and Amado Filho, 1999; Papini et al., 2011; Sordo et al., 2011) likely caused by excess nutrients (Balata et al., 2010; Burkholder et al., 2007). Although H. wrightii has been found to tolerate eutrophic waters more so than other competing species (Fourqurean et al., 1995; Lapointe et al., 1994; Powell et al., 1989), nutrient enrichment will greatly increase epiphytic biomass which effects seagrass productivity (Wear et al., 1999).

The aims of the present study were to examine the anthropogenic and natural environmental drivers that modify $H$. wrightii at a shoot and a meadow scale in order to describe and define what are the major factors affecting the development of these seagrasses. By better understanding these drivers, it is possible to compare the shoot and meadow scale responses of this tropical species to other seagrasses and ascertain whether these meadows could be under threat from these impacts.

\section{Method}

\subsection{Study sites}

Anecdotal evidence indicates seagrass meadows in Brazil are extensive, yet knowledge of seagrasses in the southwest Atlantic still remains poor (Barros et al., 2013). Recent evidence suggests that although these tropical coastal meadows are of key importance to fisheries (Nordlund et al., 2016) they are under threat, requiring concerted conservation action (Copertino et al., 2016). The coast of Brazil is subjected to intense environmental threats due to the high levels of urbanisation and frequent periods of prolonged intense rainfall (Copertino et al., 2016; Marques et al., 2004). Many areas along the coast are affected by high levels of nutrients from untreated sewage and industrial discharges as well as waters laden with suspended solids diverted from surrounding basins suffering from soil erosion (Marques et al., 2004). This can cause areas of eutrophication where flushing from fresh seawater is reduced and residence time is high such as in coastal lagoons and inevitably have a direct 
impact any seagrass meadows present. The ecological and environmental characteristics of ten seagrass meadows along the coast of Rio de Janeiro state and São Paulo were quantified within the month of April, in 2017. The study sites were, in Rio de Janeiro: Praia de Manguinhos and Praia dos Ossos (Armação dos Búzios); Saco do Céu and Praia do Abraãozinho (Ilha Grande); Praia Grande and Praia do Catita (Ilha de Itacuruçá); Ilha do Japonês and Praia dos Anjos (Cabo Frio); and in São Paulo: Siriúba and Praia do Sino (Ilhabela) (figure 1).

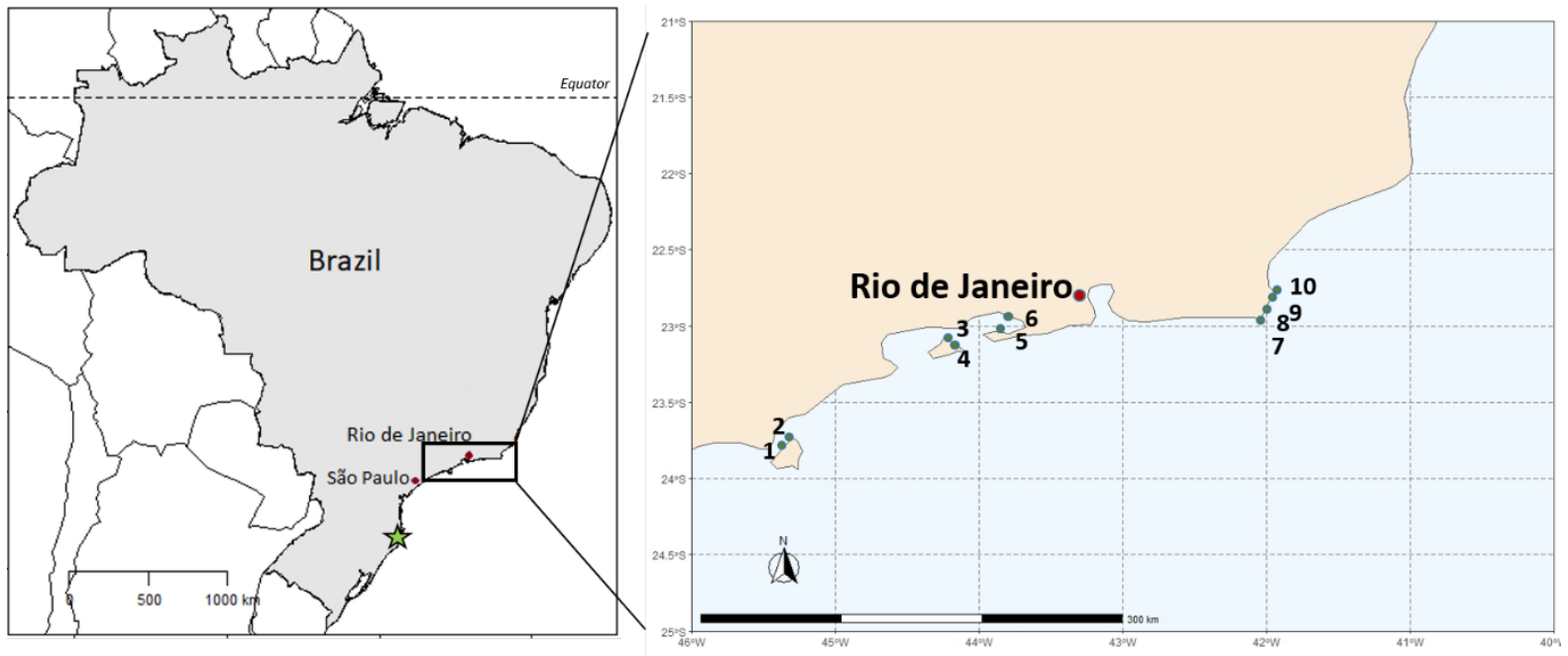

Figure 1. Left side shows distribution of seagrass sites along the coast in relation to Rio de Janeiro on the map of Brazil on the right. The sites range from from São Paulo; Siriúba (1) and Praia do Sino (2) to Rio de Janeiro; Saco do Céu (3), Praia do Abraãozinho (4), Praia do Catita (5), Praia Grande (6), Praia dos Anjos (7), Ilha do Japonês (8), Praia de Manguinhos (9) and Praia dos Ossos (10). The green star represents the southernmost extent of $H$. wrightii on the South American coast (Copertino et al., 2016).

\subsection{Environmental Impacts}

Each of the seagrass meadow sites were categorized in terms of environmental impacts. This used a scoring system developed by the authors based on methods and evidence identified from previous studies to provide an index (Creed and Oliveira, 2007; Jones and Unsworth, 2016; Oigman-Pszczol and Creed, 2011; Pitanga et al., 2012) including information collected based on site observations. The 
anthropogenic impacts that were included in the calculation of this index were as follows, included vicinity to highly urbanized area, population, industry, agriculture, boat activity, tourism, freshwater input/sewage outfall, turbidity and enclosed water body/proximity to open sea. Grazing pressure was also included as an environmental stressor. This is because turtle grazing has been found to significantly modify seagrass meadows (Lal et al., 2010), with H.wrightii found to be the most important food source for juvenile green turtles found in southern Brazil (Guebert-Bartholo et al., 2011). Each impact was scored from 0 (no impact) to 3 (high impact) and added up to give an overall value. An impact assessment index was calculated by dividing the total score for each site by the maximum possible score giving a value between 0-1 (Table A.1, Fig. 2). Impact index scores were then divided up into levels - low-medium (<0.4, SS01-SSO3), medium-high (0.4-0.5, SSO4-SS07) and high (>0.51, SS08-SS10) categories for statistical analysis.

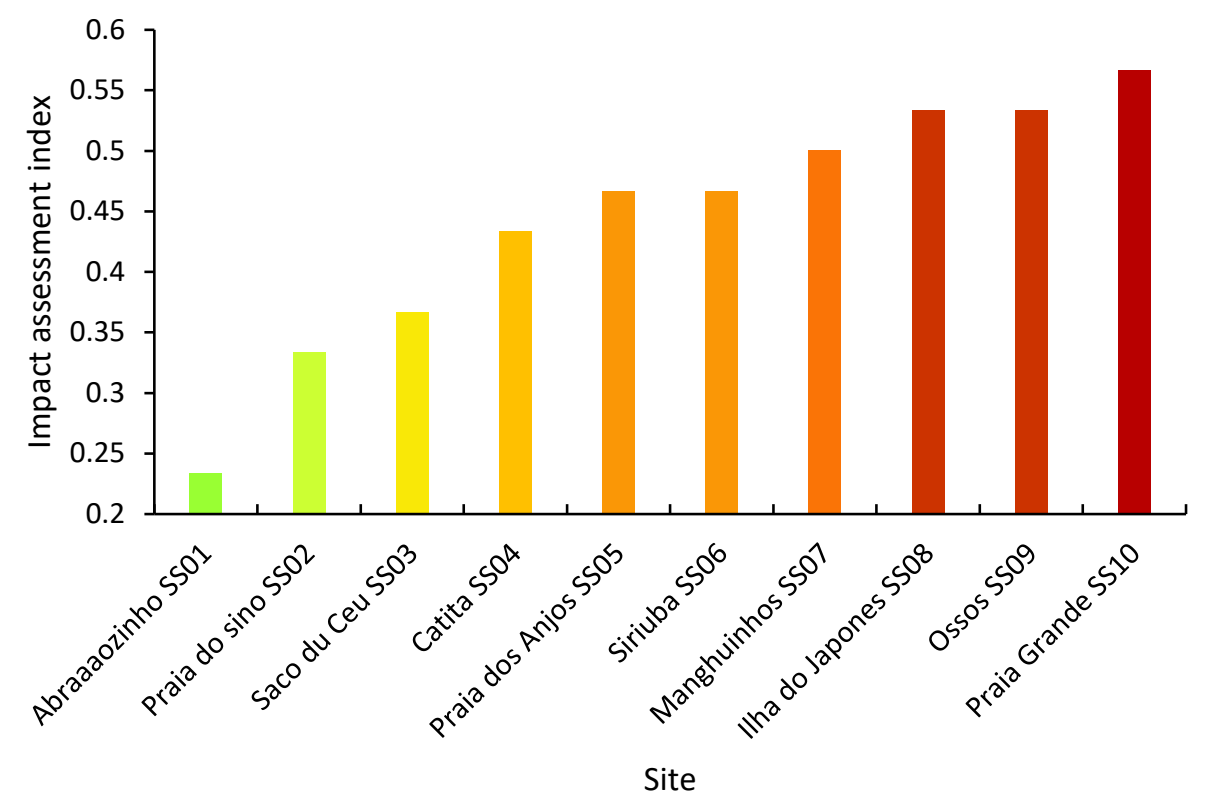

Figure 2. Environmental impact index calculated from perceived impacts scored for each seagrass site creating a gradient of increasing impact. Sites are ordered from lowest to highest perceived impact index and labelled SS01-SS10. The perceived impacts included vicinity to industry, tourism, vicinity to 
highly urbanized area, population, agriculture, boat activity, freshwater input/sewage outfall, turbidity, enclosed water body/proximity to open sea and evidence of grazing.

\subsection{Environmental data}

At each site Hobo light loggers (Onset Hobo UA-002-64) were used to measure light availability and temperature in the middle of the seagrass bed and at the deepest edge to provide light levels at maximum depth threshold. Another light logger was placed in a location on land to record irradiance at or near the sea surface so that the percentage of surface irradiance (\%SI) reaching the deep edge could be calculated to represent minimum light requirements. At each site a Secchi disk was used horizontally to estimate turbidity and salinity was recorded using a calibrated refractometer.

\subsection{Meadow characteristics}

The position of mid-meadow and meadow edges were identified by snorkelling along transects throughout each site. Percentage coverage was measured using a $50 \mathrm{~cm} \times 50 \mathrm{~cm}$ quadrat. Twelve quadrats were randomly placed along a single transect line (50 -10 m depending on size of meadow) running parallel to the shore through the middle of the seagrass meadow. This was repeated along the outer edge of the meadow. Cores of seagrass were collected using a PVC corer $\left(78.5 \mathrm{~cm}^{2}\right.$ to a depth of $15 \mathrm{~cm}$ ) within six of the twelve quadrats (every other quadrat) to obtain other seagrass parameters (Howard et al., 2014; Mills and Berkenbusch, 2009). Within each core sample, the number of shoots were counted, and the length and width of each leaf was measured using a ruler and calipers. An epiphyte cover score was recorded for each leaf based on the index developed for wasting disease (Burdick et al., 1993) and adapted for use for long-term monitoring of epiphyte cover on seagrass (Bull and Kenyon, 2015; Cook, 2011; Cook and Paver, 2007) (Table A.2). Where shoot density was very high, a maximum number of 16 shoots were measured per core and the total number of shoots was recorded. The core samples were washed, dried and then weighed to provide a total dry weight measurement (Table A.2). 


\subsection{Photo-physiological parameters}

Pulse Amplitude Modulated (PAM) fluorometry using a Diving-PAM (Waltz), was used to measure chlorophyll fluorescence for assessing photosynthetic activity. Photosynthetic parameters were obtained by performing rapid light curves using the internal stepwise function of the PAM fluorometer once attached to the mid part of $H$. wrightii leaves using a leaf clip. Rapid light curves (RLCS) were started immediately after attachment of the clip to enable the measurement of effective quantum yield $\left(\phi p s \mid l=\left(F m^{\prime}-F\right) / F m^{\prime}\right)$, where $F$ is fluorescence yield and $F m^{\prime}$ is maximal fluorescence yield of the light adapted leaf at each irradiance step (Collier et al., 2009b; Ralph and Gademann, 2005). Steps ranged from 0-2300 $\mu \mathrm{mol}$ photons $\mathrm{m}^{-2} \mathrm{~s}^{-1}$ and were carried out close to midday, between 11am and 1pm. The stepwise RLCs were fitted to the non-linear least-squares regression model by Eilers and Peeters (Eilers \& Peeters 1988) using the WinControl software (Waltz) to give photosynthetic parameters for the $\mathrm{ETR}_{\max }$ (maximum rate of photosynthesis), $\alpha$ (light harvesting efficiency) and $\mathrm{E}_{\mathrm{k}}$ (minimum saturating irradiance).

\subsection{Leaf nutrient analysis}

Samples of seagrass were taken randomly from within each of the sites. Leaves were separated, scraped free of epiphytes, and dried. Of the dried plant material collected and transported back to the UK for analysis, unfortunately there was only enough material to provide one sample per meadow once ground up due to the small leaf size of the plants. The dried seagrass was ground up with a pestle and mortar to a fine homogenous powder. Samples were sent to OEA laboratories Limited for analysis of the \% composition of Carbon, Nitrogen and Phosphorus by weight using a continuous flow isotope ratio mass spectrometer (Sercon 20-20 IRMS coupled to Thermo EA1110 elemental analyser). The ratios of stable isotope ${ }^{13} \mathrm{C}$ to ${ }^{12} \mathrm{C}\left(\delta^{13} \mathrm{C}\right)$ indicates the deviation of the isotopic composition relative to the Vienna PeeDee Belemnite (VPDB) standard. The ratios of stable isotope ${ }^{15} \mathrm{~N}$ to ${ }^{14} \mathrm{~N}\left(\delta^{15} \mathrm{~N}\right)$ indicates the deviation of the isotopic composition relative to the international standard of air. The elemental ratio of $\mathrm{C}: \mathrm{N}$ was calculated on a mole:mole basis using atomic weights ( $\mathrm{C}=12.011, \mathrm{~N}=14.007$ ) 
(McKenzie et al., 2011). These factors were determined to give values which indicate nutrient availability, anthropogenic sources of nutrients (Jennings et al., 1997; Lepoint et al., 2004) and light availability (Cabaço et al., 2008b; Collier et al., 2009; Grice et al., 1996; McMahon et al., 2013).

\subsection{Statistical analysis}

All the data was divided into measurements collected on a shoot scale and measurements taken at a meadow scale from quadrat data to perceive the environmental effects at these two levels. Parameters measured at shoot scale include average leaf length, leaf width and epiphyte cover. Meadow scale variables included shoot density, dry weight and the photosynthetic parameters Alpha, $\mathrm{ETR}_{\max }$ and $\mathrm{E}_{\mathrm{k}}$.

All measurement data was analysed using two-way ANOVA tests with impact category and site as a random factor (Brown et al., 1974; McDonald, 2014). In cases where data residuals did not follow a normal distribution, ANOVA was used but with significant $p$-values set to 0.01 to minimize risk of Type I error (Collier et al., 2012; McDonald, 2014; Underwood, 1997). Tukey HSD post-hoc multi comparison test was used for comparing ANOVA data.

Principal Component Analysis (PCA) (Clarke and Warwick, 2001) was performed on all quadrat level measurements at both shoot and meadow scale to illustrate the correlations between various shoot response parameters and effects of the perceived impacts upon them. Principal components with eigenvalues greater than 1 and eigenfactors or variable coefficients $\leq-0.3$, or $\geq 0.3$ were selected.

General Additive Models (GAMs) (Zuur et al., 2009) were carried out in order to identify any non-linear patterns with other possible explanatory factors including abiotic measurements, leaf nutrient content and stable isotopes to determine if these are affecting the abundance of seagrass at sites. Variance inflation factor analysis (VIF) was used to identify collinearity between explanatory variables and those with the highest collinearity were removed from the model. These included $\% \mathrm{C}, \% \mathrm{~N}, \mathrm{E}_{\mathrm{k}}$, 
Secchi distance and leaf width. A base GAM model was then created using shoot density as the response variable as it most commonly used factor for monitoring changes in meadows (Burton et al., 2015; Krause-jensen et al., 2005; Mckenzie et al., 2016; Short et al., 2006; Taylor et al., 2003). Alpha, dry weight, leaf length, $\mathrm{C}: \mathrm{N}, \delta^{13} \mathrm{C}, \delta^{15} \mathrm{~N}$, and impact index as explanatory factors and site as a random variable. All covariates were analysed as smooth variables (f) apart from impact index which was treated as a factor variable $(\mathrm{F})$ and nutrient data owing to small sample sizes.

(1) $E[$ shoot density $]=f($ Alpha $)+f($ dry weight $)+f($ leaf length $)+f(C: N)+f(\delta 13 C)+f(\delta 15 N)+$ f(impact index $)+F($ site $)$

The best explanatory models were chosen using manual stepwise selection based on the adjusted $\mathrm{R}^{2}$ and deviance explained values (table A.7).

All statistics were carried out using RStudio (R version 3.5.1) using R packages stats, devtools, gamm4, Ime4, mgvc, ggplot2, car and carData (R Core Team, 2018) except for PCA analysis using Primer-e V.6 (Clarke and Gorley, 2006).

\section{Results}

\subsection{Shoot scale responses}

Shoot data showed large variation between sites with average leaf length across sites found to be 25.5 $\mathrm{mm}( \pm 14.16)$, average leaf width $0.43 \mathrm{~mm}( \pm 0.22)$ and average epiphyte score $1.41( \pm 0.92)$.

The results of the two-way ANOVA shows significant interactions between leaf width ( $F=91.42$, $p=<0.001)$, leaf length $(F=14.74, p=<0.001)$ and epiphytes $(F=3.52, p=0.03)$ with impact category and site as a random factor (table A.4). For leaf width and length, the post-hoc pairwise comparison shows significant variation between plants in med-high vs high, and med-high vs low-medium impact categories (Fig. 3, table A.5), although length was found to increase with increasing impact and widest leaves found in med-high impacted meadows. The mean widths of $H$. wrightii ranged from $0.24 \mathrm{~mm}$ $( \pm 0.07)$ at $\mathrm{SS} 03$, to $0.76 \mathrm{~mm}( \pm 0.13)$ at SSO7. Average leaf length also varied greatly between meadows 
(Fig. 3), from $17.33 \mathrm{~mm}( \pm 9.26)$ at SSO9, to $40.84 \mathrm{~mm}( \pm 24.01)$ at SSO4. Epiphyte cover also varied with the lowest mean score found at SS01 $(0.63 \pm 0.83)$ which was significantly lower than all other sites, and the highest score at SSO8 $(1.86 \pm 1.43)$. Epiphyte cover was found to increase with increasing impact however it was not found to vary significantly between impact categories.

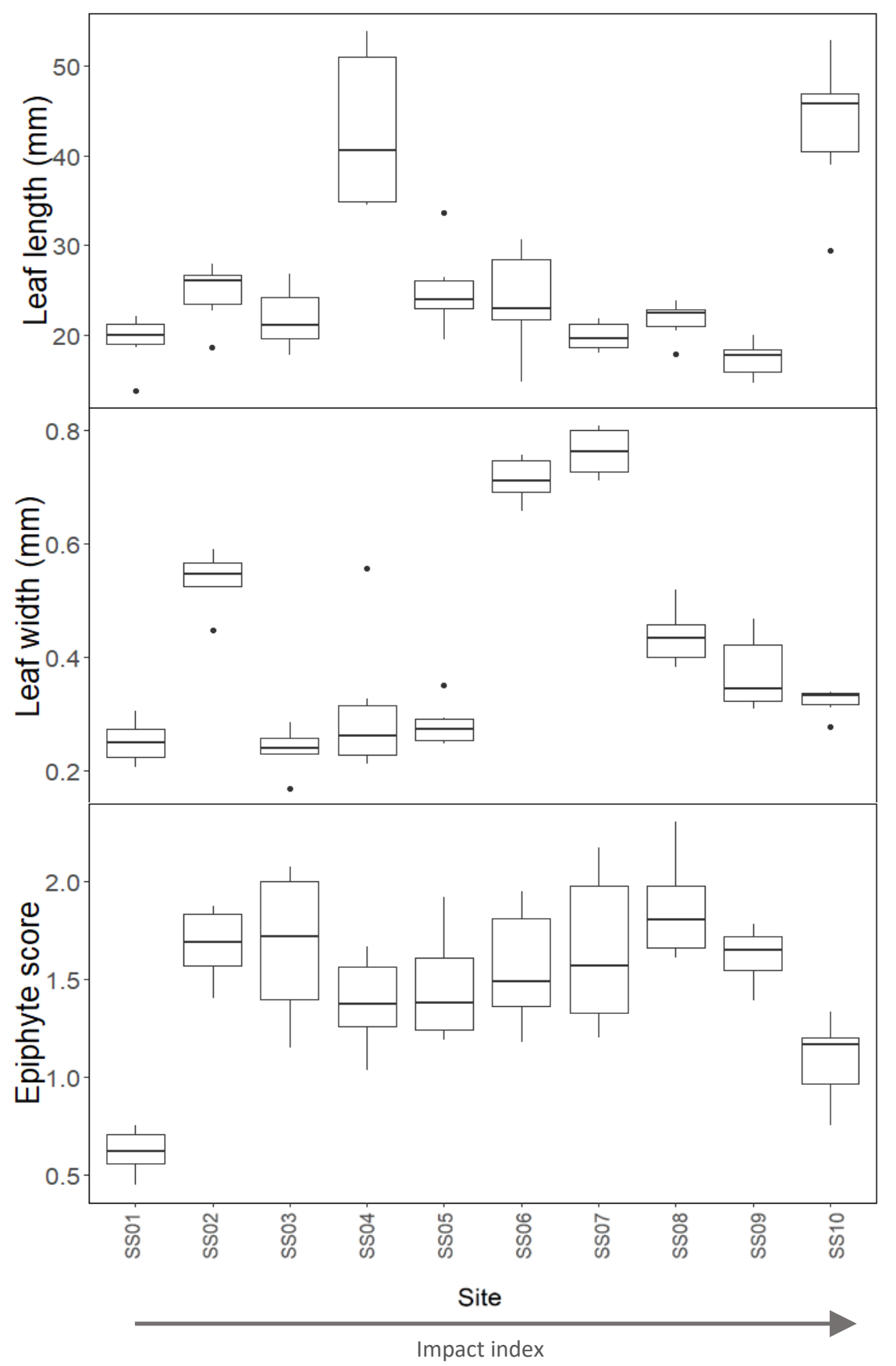


Figure 3. Boxplots to show comparison of shoot-scale responses of average leaf length, leaf width and epiphyte cover between seagrass sites ( $n=55-96$ per site). Median is indicated by the solid line, outliers indicated by dots. Site order from lowest impact index score (SSO1) on left to highest (SS10) on the right.

\subsection{Meadow scale responses}

Meadow scale variables also showed high variation across sites, with average shoot density ranging from $764.33( \pm 575.36)$ to $16645.44 .7( \pm 3668.85)$ shoots $/ \mathrm{m}^{2}$ and dry weight from $3.74( \pm 1.27)$ to 104.46 $( \pm 20.4) \mathrm{g} / \mathrm{m}^{2}$

The statistical tests showed significant interactions between dry weight $(\mathrm{F}=50.08, p=<0.001)$ and shoot density ( $\mathrm{F}=66.51, p=<0.001$ ) with impact category and site as a random factor (table A.4). The posthoc pairwise comparison shows that shoot density varies significantly between each of the impact categories ( $p$ adj=<0.001) with shoot density actually increasing with impact. For total dry weight, low-medium vs high and low-medium vs med-high showed significant differences (both $p$ adj $=<0.001$, table A.5), again increasing with impact, not as expected.

Dry weight was highest in SSO4 and SS09 with an average of $104.46( \pm 20.4)$ and $91.78( \pm 19.78) \mathrm{g} / \mathrm{m}^{2}$ respectively and significantly higher than all other meadows. SSO1 had the lowest dry weight at 3.74 $( \pm 1.27) \mathrm{g} / \mathrm{m}^{2}$. SS09 had the highest shoot density, with an average of $16645.44( \pm 3668.85)$ shoots $/ \mathrm{m}^{2}$ (Fig. 4). The meadows with the lowest shoot density were SS10 (764.33 \pm 575.37 shoots $\left./ \mathrm{m}^{2}\right)$ and SSO3 $\left(1273.89 \pm 369.21\right.$ shoots $\left./ \mathrm{m}^{2}\right)$.

\subsection{Photo-physiological responses}

Photosynthetic parameters also showed high levels of variation between sites, with light harvesting efficiency (Alpha) ranging from $0.26( \pm 0.04)$ to $0.39( \pm 0.06)$, the maximum rate of photosynthesis $\left(E T R_{\max }\right)$ from $203.01( \pm 18.65)$ to $365( \pm 47.1)$ and minimum saturating irradiance $\left(E_{k}\right)$ ranging from $588.83( \pm 91.09)$ to $1083.62( \pm 131.42)$. 
Not all photo-physiological parameters showed significant interactions with impact category only $\operatorname{ETR}_{\max }(\mathrm{F}=8.62, p=<0.001)$, however they all showed significant variation between sites (table A.4). The post-hoc pairwise comparison shows only significant variation in ETR $\mathrm{max}_{\max }$ between low-medium vs high ( $p$ adj $=<0.001$ ) and low-medium vs med-high ( $p$ adj=0.007) impact categories (table A.5) with ETR max $_{\text {ma }}$ decreasing with increasing impact as would be expected.

The Alpha value recorded for seagrasses at SSO4 was significantly higher than several of the other sites $(0.39 \pm 0.06)$, followed by SS10 $(0.35 \pm 0.05)$ suggesting light limitation at these sites. The sites with

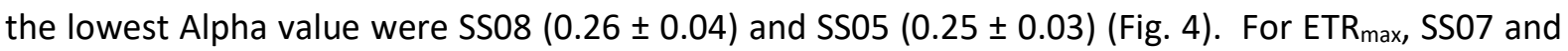
SS03 seagrass showed the highest rates, $365.99( \pm 47.43)$ and $340.3( \pm 29.28)$ respectively. These sites were significantly higher than all other sites. SS10 and SS05 had the lowest values overall (203.01 \pm 18.65 and $203.86 \pm 33.08$ respectively). For the $E_{k}$ values, the sites that significantly varied from one another included SSO8, SSO7 and SSO3 which had the highest levels $(1128.77 \pm 122.78,1183.61 \pm$ 131.42 and $1067.25 \pm 131.42$ respectively), and SS10 and SSO4 which had the lowest levels (588.83 \pm 91.09 and $644.71 \pm 91.29$ respectively, Fig. 4). 


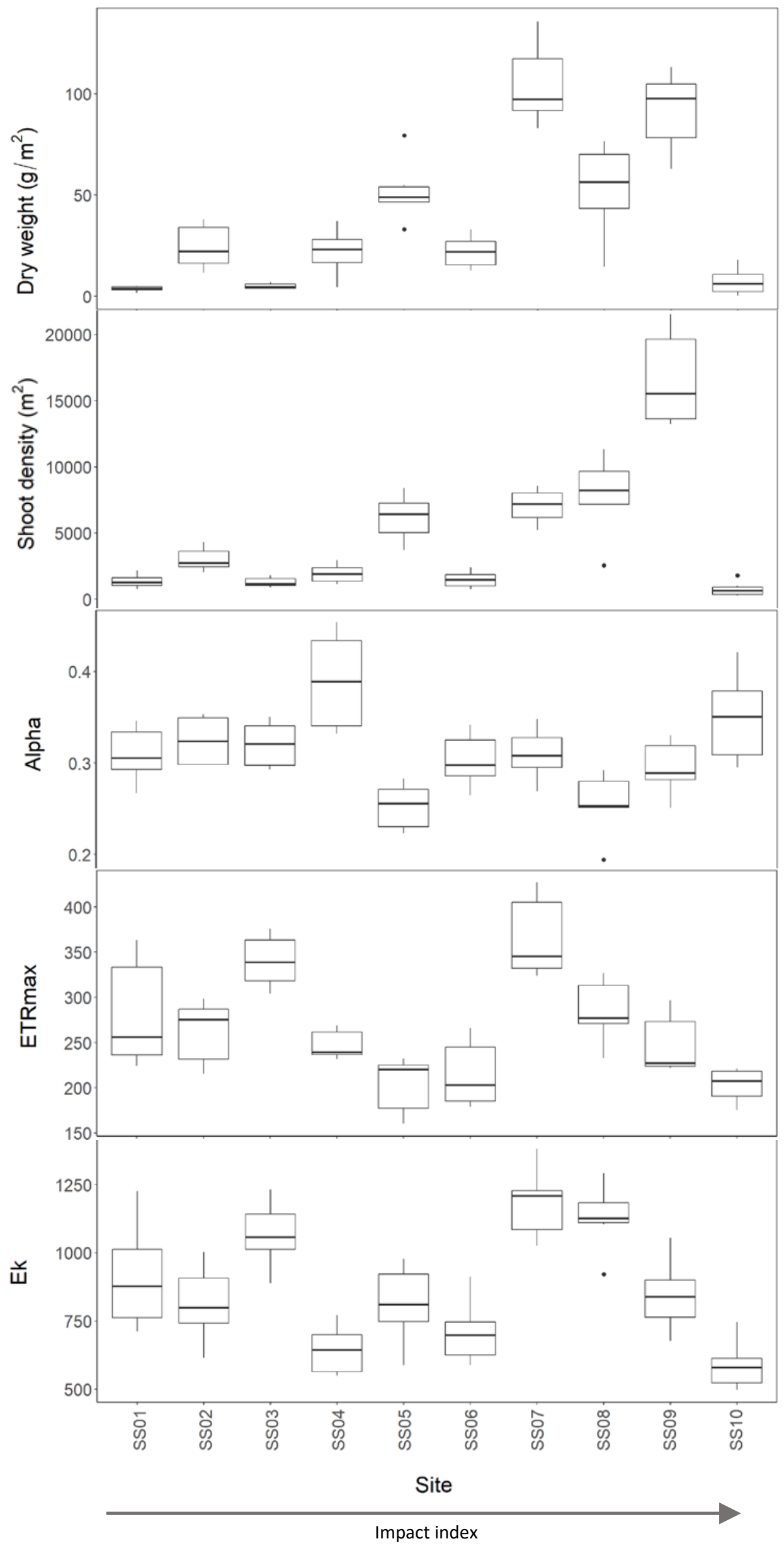


Figure 4. Boxplots to show comparison of the meadow and photo-physiological parameters, dry weight, shoot density, Alpha, ETR $\max$ and $E_{k}$ between seagrass sites $(n=6)$. Shoot density and dry weight are shown as per $\mathrm{m}^{2}$. Median is indicated by the solid line, outliers indicated by dots. Site order from lowest impact index score on left to highest on the right.

\subsection{Principal Component Analysis}

For shoot scale responses (PCA A, Fig. 5), PC1 accounted for $48.3 \%$ of the variance with an eigenvalue of 1.45. Leaf width and epiphyte cover showed the strongest responses with eigenfactors of -0.668 and -0.613 respectively, showing a negative relationship compared to leaf length (0.422). PC2 accounted for $30.7 \%$ of the variance with and eigenvalue of 0.922 . Leaf length showed the strongest level of response with an eigenfactor of 0.876 , followed by epiphyte cover with 0.464 (Table A.5).

For meadow scale responses (PCA B, Fig. 5), PC1 accounted for $48.8 \%$ of the variance with an eigenvalue of 2.44. All the seagrass variables included showed strong responses (eigenfactors over 0.3 , less than -0.3$)$, although the highest variables were $E_{k}(-0.534)$, dry weight $(-0.504)$ and shoot density $(-0.434)$ all showing negative association. PC2 explained $28.2 \%$ of the variance (eigenvalue 1.41) with all variables showing strong responses except Alpha at 0.246 , just below the level of selection (Fig. 5, Table A.5). 
(A)

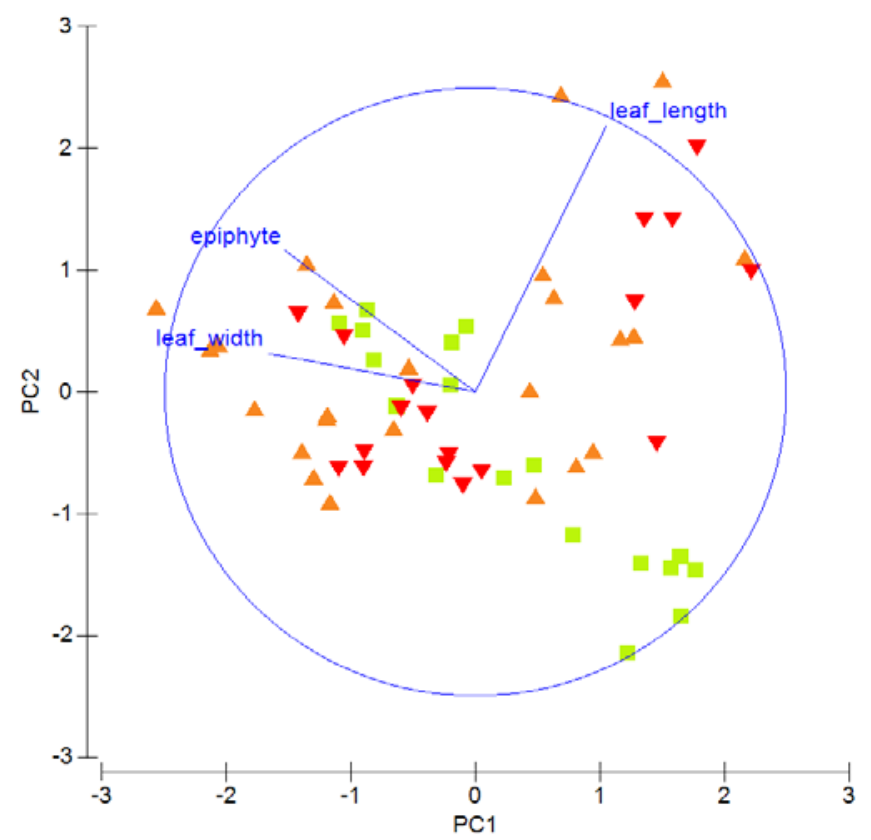

(B)

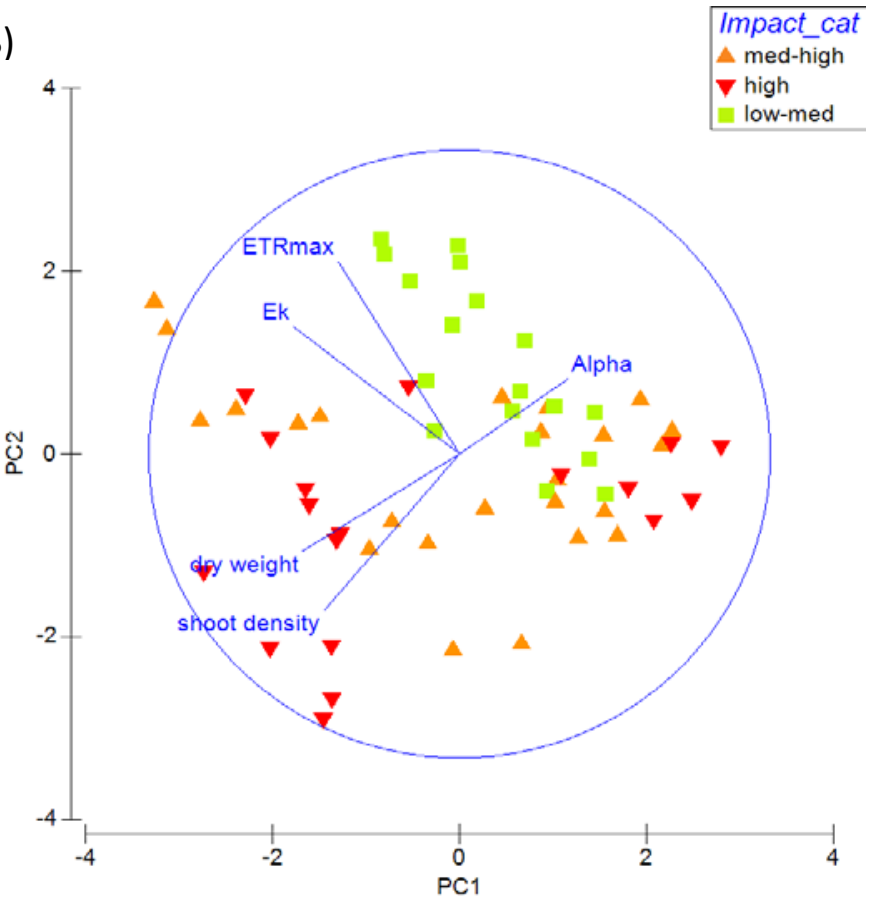

Figure 5. Principal Component Analysis of (A) shoot data (leaf width, leaf length and epiphyte cover) variation with impact score as a factor and (B) Principal Component Analysis of meadow-scale data (shoot density, dry weight and photosynthetic characteristics Alpha, ETR $R_{\max }$ and $E_{k}$ ). Legend separates sites by relative levels of impacts determined by scores and divided into low-medium $(<0.4)$, mediumhigh (0.4-0.5) and high (>0.5).

\subsection{Leaf nutrient analysis}

Results from the tissue nutrient analysis of $H$. wrightii shoots show that the highest percentage of nitrogen was found in SS10 (3.39\%) and SSO3 (3.38\%), with the average of all sites found to be 3.04 $\pm 0.23 \%$. The highest percentage of phosphorus was found in the seagrass from SSO3 (0.41\%) and SS08 $(0.40 \%)$, with the site average of $0.36 \pm 0.04 \%$. Of the sites, SSO3 displayed the lowest C:N ratio (10.44). The highest C:N ratios were found at SSO7 and SS05 (12.35 and 12.37 respectively) with the study average found to be $11.63 \pm 0.58$ (table 2 ), suggesting these sites are subjected to higher light levels than others. 
The values for $\delta^{15} \mathrm{~N}$ were highest in seagrass tissue from SS10 (7.56\%) and SSO4 (7.13\%०), followed by SS09 $(5.74 \%$ ) and SSO7 (4.99\%) all relatively higher than the study average $(4.15 \pm 2.3 \%$ ). Sites SSO3, SSO8 and SSO1 had the lowest $\delta^{15} \mathrm{~N}$ ratios $(1.0,1.68$ and $1.72 \%$ respectively) indicating substantially lower anthropogenic nutrient input at these sites than average (table 2).

Table 2. Results from the elemental analysis of $H$. wrightii leaf tissue taken from the study sites. The stable isotope values for $\delta^{15} \mathrm{~N}(\% \circ), \delta^{13} \mathrm{C}(\% \circ)$.

\begin{tabular}{lccccc}
\hline Site & $\boldsymbol{\delta}^{15} \mathbf{N}$ & $\boldsymbol{\delta}^{\mathbf{1 3}} \mathbf{C}$ & $\mathbf{\%}$ & \%P & $\mathbf{C : N}$ \\
\hline SS01 (low-med) & 1.72 & -10.95 & 3.04 & 0.38 & 12.85 \\
\hline SS02 (low-med) & 4.14 & -10.95 & 3.07 & 0.38 & 13.81 \\
\hline SS03 (low-med) & 1.00 & -10.22 & 3.38 & 0.41 & 12.17 \\
\hline SS04 (med-high) & 7.13 & -9.04 & 2.70 & 0.27 & 13.65 \\
\hline SS05 (med-high) & 4.70 & -11.09 & 2.84 & 0.38 & 14.43 \\
\hline SS06 (med-high) & 2.87 & -11.16 & 3.10 & 0.36 & 13.48 \\
\hline SS07 (med-high) & 4.99 & -10.43 & 2.72 & 0.34 & 14.40 \\
\hline SS08 (high) & 1.68 & -7.59 & 3.12 & 0.40 & 13.20 \\
\hline SS09 (high) & 5.74 & -9.40 & 3.07 & 0.37 & 13.32 \\
\hline SS10 (high) & 7.56 & -10.30 & 3.34 & 0.31 & 13.67 \\
\hline Study averages & 4.15 & -10.11 & 3.04 & 0.36 & 13.50 \\
\hline S.D. & 2.30 & 1.13 & 0.23 & 0.04 & 0.68 \\
\hline Range & $1.0-7.56$ & $-11.16--7.59$ & $2.7-3.38$ & $0.27-0.41$ & $12.17-14.43$ \\
\hline
\end{tabular}

The ratio of $\delta^{13} \mathrm{C}$ in $H$. wrightii shoots averaged $-10.11 \pm 1.13 \%$ o with little variation between all sites.

The lowest $\delta^{13} \mathrm{C}$ was found in Siriuba (-11.16\%) and Praia dos Anjos (-11.09) and the highest $\delta^{13} \mathrm{C}$ found in the seagrass at llha do Japonês (-7.59) (Table 2).

\subsection{Generalized Additive Models to describe shoot density}

After removal of collinear variables and those that were non-significant or would not converge within the GAM models owing to unbalanced sample size, the final model consisted of $\delta^{15} \mathrm{~N}$, leaf length and impact index:

(2) $E[$ shoot density $]=f($ impact $)+f\left(\delta^{15} N\right)+f($ leaf length $)+F($ site $)$ 
Basic models were compared for best fit. All variables that were deemed insignificant, having little effect were removed. Site as a random factor and Impact level were also removed to test effect on model fit with results of the final comparisons in table A.7.

The first GAM model provides evidence that the impact level (low), alpha, leaf length and shoot $\delta^{15} \mathrm{~N}$ are highly significant in explaining shoot density between impact categories, with highest deviance explained (96.5\%, R-sq adj. 0.978) and lowest GVC of all models tested (table A.7). The tissue $\delta^{15} \mathrm{~N}$ increases with impact level as expected, however shoot density and leaf length also increase with increasing impact levels. Model 5 which takes out impact level shows leaf length is highly significant as well as site at explaining shoot density, however $\delta^{15} \mathrm{~N}$ could not be included at this level owing to small sample size.

\section{Discussion}

The plasticity of seagrass meadows to environmental stressors enables them to be bioindicators of ecological change in coastal waters. The present study demonstrates that although such responses occur and do indicate the majority of seagrasses in a region of Brazil to be under anthropogenic stress, their responses are multifaceted and often difficult to interpret with respect to assessing the environmental status of seagrass meadows. One of the major attributes considered for assessing seagrass health and resistance is abundance (Unsworth et al., 2015), with increasing abundance potentially leading to increased resilience (Mckenzie et al., 2016). The present study indicates that this assumption may not always be correct as reduced shoot density and biomass did not always reflect increasing anthropogenic impact. Other indicators were found to be more robust to identifying environmental risks. Epiphyte score, and leaf nutrient content $\left(\delta^{15} \mathrm{~N}, \% \mathrm{~N}, \% \mathrm{P}\right.$ and $\left.\mathrm{C}: \mathrm{N}\right)$ data supported what were assessed to be the low-medium impacted sites (SSO1 and SSO3), and leaf nutrients were found to be highest in plants from the site predicted to be of high impact (SS10), indicating nutrient enrichment. Other meadow scale responses also supported the case that SS10 is likely to be the most 
impacted site displaying the lowest shoot density, ETR $R_{\max }$ and $E_{k}$ of all sites, and second highest Alpha. However, other meadow-scale responses specifically the low shoot density and biomass at SSO1, do not support the low-medium impact assessment index attributed. The input of naturally occurring nutrients from adjacent mangroves or potential for higher levels of exposure to wave action and recent storm events could have resulted in a decrease in shoot density at this site.

The shoots with the longest leaves were found at SSO4 (med-high) and SS10 (high), although leaf widths at these sites were relatively narrow. The seagrass within medium-high impact sites (SSO6 and SS07) were found to have the widest leaves, but also amongst the shortest leaves measured. It is expected that nutrient enrichment within the water-column results in increased turbidity and light attenuation, caused by an increase in epiphytic algae growth and eutrophication. Light limitation often results in a reduction of above-ground biomass exhibited by shorter, narrower leaves, with fewer leaves per shoot and becoming less dense at a meadow scale (Bertelli and Unsworth, 2018; Biber et al., 2005; Collier et al., 2012; Ochieng et al., 2010; Olesen and Sand-jensen, 1993; Yaakub et al., 2013). However, reduction in leaf length and elongation which is exhibited in many seagrass species as a response to light limitation does not always hold true for $\mathrm{H}$. wrightii. This study has found the sites with the longest leaves were also found to have highest levels of shoot $\delta^{15} \mathrm{~N}$, Alpha, turbidity and lowest shoot density and $E_{k}$ indicating poor water quality and low light conditions. Creed (1999) also found that shoot density to be highest in meadows with shorter leaves. Previous studies have found that $H$. wrightii can show little change in leaf elongation from shading experiments (Czerny and Dunton, 1995), and in situ, H. wrightii growing in shade can have longer leaf lengths than neighbouring plants growing under higher light conditions (Shafer, 1999). Leaf length could also have been affected by the presence of turtles observed by the authors, the effect of which has been observed to cause $H$. wrightii in this area to grow wider leaves (Creed, pers. Comm., 2017). There was found to be a relationship between wider leaves of $H$. wrightii and evidence of grazing (turtle presence and cropped leaves, see A.1). However this response also appears to be species specific and the converse of 
findings from other studies that found grazing to have the opposite effect (Fourqurean et al., 2010; Lacey et al., 2014; Lal et al., 2010).

There is a wide body of evidence which shows that light limitation and shading results in a reduction in shoot production and shoot density overall for H. wrightii (Biber et al., 2009; Shafer, 1999) and other seagrass species (Lee and Dunton, 1997; Longstaff et al., 1999; Olesen et al., 2002), highlighting this response as a major indication of light stress at a meadow-scale. According to the meadow-scale attributes measured (density, biomass, and photosynthetic stress), SS10 (high) is likely to be the most light-stressed, followed by SSO4 (med-high). These sites are located within the semi-enclosed, shallow Sepetiba Bay, with lower flushing, into which flow several rivers draining the catchment of the highly urbanised and industrial city of Rio de Janeiro. This is also supported by the high turbidity and temperatures recorded in situ. SSO6 also showed similar meadow-scale indicators of stress to SSO4 and SS10 which could also be explained by the high level of turbidity found at the site and the low \% SI reaching the seagrass (Table A.3). This site is within protected and enclosed São Sebastião Channel, also with lower flushing. Shoot density and dry weight show similar patterns for the sites as expected, which are also reflected in the values for alpha which are highest in those meadows which appear to be the most impacted.

The $H$. wrightii at SS10 was found to have the second highest level of nitrogen and the highest $\delta^{15} \mathrm{~N}$ indicating nutrient enrichment affecting the site is likely to include anthropogenic sources. Seagrass from SSO3 was also found to have a high proportion of nitrogen, however its low $\delta^{15} \mathrm{~N}$ isotopic ratio indicates that there are lower anthropogenic inputs at this site. This site is also within an enclosed embayment, part of the Ilha Grande State Park, where nutrient inputs likely come from leaf litter from the adjacent preserved Atlantic rainforest and mangrove systems rather than from the sparse human habitations. The carbon to nitrogen ratio found within seagrass leaves has been found to be a robust indicator of light stress which responds over a longer time-scale than photosynthetic characteristics (McMahon et al., 2013). The results from this study suggest that SS07 and SS05 (med-high) are 
subjected to a higher light environment overall, and the site subjected to the lowest light levels over time is likely to be $\mathrm{SSO3}$ (low-medium). However, it should be considered that the overall C:N ratios between sites showed little variation suggesting all the sites are subjected to relatively low light conditions and high nutrient status. With global averages for other seagrass species found to be considerably higher at around 20 (Atkinson and Smith, 1983; Duarte, 1990; Grice et al., 1996; Jones and Unsworth, 2016), the low site averages found in this study support such a premise although more samples should be taken in the future to support this. Increasing irradiance has also been found to lower isotopic discrimination of carbon uptake during photosynthesis in seagrasses and therefore lower $\delta^{13} \mathrm{C}$ depletion within the plants. This suggests that the seagrass meadow at SSO8 (high) is subjected to the highest light levels of all sites measured in this study which is supported with it being the shallowest meadow and highest \% surface irradiance levels recorded (Tables 2, A.3). To the author's knowledge this is the first study that has analysed the $\mathrm{C}: \mathrm{N}$ and stable isotopes of $\mathrm{H}$. wrightii using modern methods of mass spectrophotometry, and despite low sample number, does provide important evidence for this seagrass species. A previous study by Powell et al. (1989) quantified the nitrogen and phosphorus content of $\mathrm{H}$. wrightii plants before and after nutrient enrichment with results showing concentrations lower than those found at all ten sites measured for this study. Monitoring reports describe seagrasses with tissue nutrient ratios $(\mathrm{C}: \mathrm{N})$ below 15 as very poor (Mckenzie et al., 2016; McKenzie et al., 2011) which suggests that all sites in this study are nutrient enriched. The opportunistic and pioneering nature of $H$. wrightii allows it to grow in relatively unstable conditions compared to other seagrass species (Creed and Amado Filho, 1999; Lapointe et al., 1994; Tomasko and Lapointe, 1991; Wear et al., 1999). These unstable conditions can result in sedimentation and burial, a factor not measured in the present study, but has been found to be one of the most important causes of localised loss (Cabaço et al., 2008b; Ceccherelli et al., 2018). H. wrightii has a higher nutrient demand than other seagrasses (Powell et al., 1989; Wear et al., 1999) and so can better tolerate eutrophication (Lapointe et al., 1994) and has been known to displace Thalassia testudinum under conditions of prolonged nutrient enrichment (Fourqurean et al., 1995). 
Yet, enrichment has been found to significantly decrease blade turnover and rhizome growth in other species (Wear et al., 1999), and coupled with sedimentation from anthropogenic caused run-off or natural storm events can cause considerable decline (Ceccherelli et al., 2018). Nevertheless it is expected that the variation in morphology, density and physiology of $H$. wrightii meadows is caused by differences in localised environmental conditions which have been found to be greater at its southern distributional limit (Creed, 1997; Sordo et al., 2011).

\section{Conclusion}

This study assessed seagrass indicators at shoot and meadow-scales across a range of seagrass meadows, and the environmental parameters which are modifying them. The results demonstrate substantial morphological and physiological variation to occur.

The results of this study have shown that although perceived impacts and undesirable environmental conditions are the cause of variation between these relatively isolated populations, it is not straight forward to identify which sites are most impacted in the case of Halodule wrightii. The impact assessment index developed in this study identified SS10 as the most impacted site which is reflected in the meadow scale responses; lowest shoot density, ETR $\mathrm{max}_{\max }$ and $E_{k}$ of all sites, and second highest alpha. The shoot nutrient analysis also confirms that SS10 is probably one of the most eutrophic sites owing to the highest $\% \mathrm{~N}$ content of the leaves. However, the impact index perceives SSO1 as the least impacted site but the low shoot density, biomass and leaf widths at this site go some way to contradict this. Other processes that have not been recorded could be responsible for the condition of the seagrass here, its location on the northern side of Ilha Grande is more exposed and potentially subjected to more storm events which could cause burial. It has also previously been rated as the most heavily impacted site within the Baía da Ilha Grande (Creed and Oliveira, 2007). The impact index has been shown to work for assessing the most impacted sites but has not been so useful at determining the least impacted, most likely due to naturally occurring drivers that were not measured. 
Of the variables measures, the stable isotope of Nitrogen and leaf length were most significant in explaining the differences in shoot density between sites. Taking more samples for shoot $\mathrm{C}: \mathrm{N}$ and stable isotope analysis is highly recommended to substantiate this trend. All the seagrass sites used in this study are relatively impacted, with some more than others although $H$. wrightii may also naturally better tolerate more borderline environmental conditions that other seagrasses do not. This highlights the importance of identifying the most species appropriate factors to measure when attempting to assess the health status of seagrass meadows, which could result in the development of monitoring protocols that incorporate species specific responses to site specific threats.

\section{Acknowledgements}

We thank Marcelo Mantelatto, Mariana Aguiar and Juliana Magalhaes for help with fieldwork. This work was supported by Fundação Carlos Chagas Filho de Amparo à Pesquisa do Estado do Rio de Janeiro (JCC, FAPERJ- E26/201.286/2014) and Conselho Nacional de Desenvolvimento Científico e Tecnológico (JCC, CNPq- 307117/2014-6) and Santander staff mobility funding through Swansea University. We also thank Dr Pippa Moore and Aberystwyth University for allowing us the use of their Diving PAM fluorometer.

\section{References}

Atkinson, M., Smith, S., 1983. C: N: P ratios of benthic marine plants. Limnol. Oceanogr. 568-574.

Balata, D., Piazzi, L., Nesti, U., Bulleri, F., Bertocci, I., 2010. Effects of enhanced loads of nutrients on epiphytes on leaves and rhizomes of Posidonia oceanica. J. Sea Res. 63, 173-179. https://doi.org/10.1016/j.seares.2009.12.001

Barros, K.V.D.S., Rocha-Barreira, C.D.A., Magalhães, K.M., 2013. Ecology of Brazilian seagrasses: Is our current knowledge sufficient to make sound decisions about mitigating the effects of climate change? Iheringia Ser. Bot. 68, 163-178.

Bertelli, C.M., Unsworth, R.K.F., 2018. Light Stress Responses by the Eelgrass, Zostera marina (L). Front. 
Environ. Sci. 6, 1-13. https://doi.org/10.3389/fenvs.2018.00039

Biber, P.D., Kenworthy, W.J., Paerl, H.W., 2009. Experimental analysis of the response and recovery of Zostera marina (L.) and Halodule wrightii (Ascher.) to repeated light-limitation stress. J. Exp. Mar. Bio. Ecol. 369, 110-117. https://doi.org/10.1016/j.jembe.2008.10.031

Biber, P.D., Paerl, H.W., Gallegos, C.L., Kenworthy, W.J., Fonseca, M.S., 2005. Evaluating indicators of seagrass stress to light. Estuar. Indic. 193-209. https://doi.org/doi:10.1201/9781420038187.ch13

Bité, J.S., Campbell, S.J., McKenzie, L.J., Coles, R.G., 2007. Chlorophyll fluorescence measures of seagrasses Halophila ovalis and Zostera capricorni reveal differences in response to experimental shading. Mar. Biol. 152, 405-414. https://doi.org/10.1007/s00227-007-0700-6

Brown, M.B., Forsythe, A.B., Brown, M.B., Forsythe, A.B., 1974. The Small Sample Behavior of Some Statistics Which Test the Equality of Several Means. Technometrics 16, 129-132. https://doi.org/10.1080/00401706.1974.10489158

Bull, J., Kenyon, E., 2015. Isles of Scilly eelgrass bed voluntary monitoring programme 2015 Annual Survey A report for Natural England.

Burdick, D.M., Short, F.T., Wolf, J., 1993. An index to assess and monitor the progression of wasting disease in eelgrass Zostera marina. Mar. Ecol. Prog. Ser. 94, 83-90. https://doi.org/10.3354/meps094083

Burkholder, J.M., Tomasko, D.A., Touchette, B.W., 2007. Seagrasses and eutrophication. J. Exp. Mar. Bio. Ecol. 350, 46-72. https://doi.org/10.1016/j.jembe.2007.06.024

Burton, M., Lock, K., Clabburn, P., Griffiths, J., Newman, P., 2015. Skomer Marine Conservation Zone. Distribution \& Abundance of Zostera marina in North Haven 2014. NRW Evidence Report No. 68.

Cabaço, S., Machás, R., Viera, V., Santos, R., 2008a. Impacts of urban wastewater discharge on seagrass meadows (Zostera noltii). Estuar. Coast. Shelf Sci. 78, 1-13. https://doi.org/10.1016/j.ecss.2007.11.005

Cabaço, S., Santos, R., Duarte, C.M., 2008b. The impact of sediment burial and erosion on seagrasses : A review. Estuar. Coast. Shelf Sci. 79, 354-366. https://doi.org/10.1016/j.ecss.2008.04.021 
Campbell, S.J., Miller, C.J., 2002. Shoot and abundance characteristics of the seagrass Heterozostera tasmanica in Westernport estuary (south-eastern Australia). Aquat. Bot. 73, 33-46. https://doi.org/10.1016/S03043770(02)00002-5

Carruthers, T.J.B., Tussenbroek, B.I. Van, Dennison, W.C., 2005. Influence of submarine springs and wastewater on nutrient dynamics of Caribbean seagrass meadows. Estuar. Coast. Shelf Sci. 64, 191-199. https://doi.org/10.1016/j.ecss.2005.01.015

Ceccherelli, G., Oliva, S., Pinna, S., Piazzi, L., Procaccini, G., Marin-Guirao, L., Dattolo, E., Gallia, R., La Manna, G., Gennaro, P., Costa, M.M., Barrote, I., Silva, J., Bulleri, F., 2018. Seagrass collapse due to synergistic stressors is not anticipated by phenological changes. Oecologia 186, 1137-1152. https://doi.org/10.1007/s00442-018-4075-9

Clarke, K., Gorley, R., 2006. PRIMER version 6: user manual/Tutorial.

Clarke, K.R., Warwick, R.M., 2001. Change in Marine Communities: An Approach to Statistical Analysis and Interpretation.

Collier, C.J., Adams, M.P., Langlois, L., Waycott, M., O’Brien, K.R., Maxwell, P.S., McKenzie, L., 2016. Thresholds for morphological response to light reduction for four tropical seagrass species. Ecol. Indic. 67, 358-366. https://doi.org/10.1016/j.ecolind.2016.02.050

Collier, C.J., Lavery, P.S., Ralph, P.J., Masini, R.J., 2009. Shade-induced response and recovery of the seagrass Posidonia sinuosa. J. Exp. Mar. Bio. Ecol. 370, 89-103. https://doi.org/10.1016/j.jembe.2008.12.003

Collier, C.J., Waycott, M., Ospina, A.G., 2012. Responses of four Indo-West Pacific seagrass species to shading. Mar. Pollut. Bull. 65, 342-354. https://doi.org/10.1016/j.marpolbul.2011.06.017

Cook, K.J., 2011. Report on 2011 Isles of Scilly Zostera marina survey.

Cook, K.J., Paver, L.F.C., 2007. Isles of Scilly Zostera marina monitoring 2007 Expedition Report.

Copertino, M.S., Creed, J.C., Lanari, M.O., Magalhaes, K., Barros, K., Lana, P.C., Sordo, L., Horta, P.A., 2016. Seagrass and submerged aquatic vegetation (VAS) habitats off the coast of Brazil: State of knowledge, 
conservation and main threats. Brazilian J. Oceanogr. 64, 53-80. https://doi.org/10.1590/S1679-

\section{$875920161036064 s p 2$}

Creed, J.C., 1999. Distribution, seasonal abundance and shoot size of the seagrass Halodule wrightii near its southern limit at Rio de Janeiro state, Brazil. Aquat. Bot. 65, 47-58. https://doi.org/10.1016/S03043770(99)00030-3

Creed, J.C., 1997. Morphological variation in the seagrass Halodule wrightii near its southern distributional limit. Aquat. Biol. 59, 163-172.

Creed, J.C., Amado Filho, G.M., 1999. Disturbance and recovery of the macroflora of a seagrass (Halodule wrightii Ascherson) meadow in the Abrolhos Marine National Park, Brazil: An experimental evaluation of anchor damage. J. Exp. Mar. Bio. Ecol. 235, 285-306. https://doi.org/10.1016/S0022-0981(98)00188-9

Creed, J.C., Oliveira, A.E.S., 2007. Uma Metodologia e Analise de Impactos Ambientais, in: Biodiversidade Marinha Da Baia Da Ilha Grande. pp. 351-377.

Czerny, A.B., Dunton, K.H., 1995. The effects of in situ light reduction on the growth of two subtropical seagrasses, Thalassia testudinum and Halodule wrightii. Estuaries 18, 418-427. https://doi.org/10.2307/1352324

Duarte, C., 1990. Seagrass nutrient content. Mar. Ecol. Prog. Ser. 67, 201-207. https://doi.org/10.3354/meps067201

Duarte, C.M., 2002. The future of seagrass meadows. Environ. Conserv. 29, 192-206. https://doi.org/10.1017/S0376892902000127

Fourqurean, J.W., Boyer, J.N., Durako, M.J., Hefty, L.N., Peterson, B.J., 2003. Forecasting Responses of Seagrass Distributions To Changing Water Quality Using Monitoring Data. Ecol. Appl. 13, 474-489. https://doi.org/10.1890/1051-0761(2003)013[0474:frosdt]2.0.co;2

Fourqurean, J.W., Manuel, S., Coates, K.A., Kenworthy, W.J., Smith, S.R., 2010. Effects of excluding sea turtle herbivores from a seagrass bed: Overgrazing may have led to loss of seagrass meadows in Bermuda. Mar. Ecol. Prog. Ser. 419, 223-232. https://doi.org/10.3354/meps08853 
Fourqurean, J.W., Moore, T.O., Fry, B., Hollibaugh, J.T., 1997. Spatial and temporal variation in C:N:P ratios, $\delta 15 \mathrm{~N}$ and $\delta 13 \mathrm{C}$ of eelgrass Zostera marina as indicators of ecosystem processes, Tomales Bay, California. Mar. Ecol. Prog. Ser. 157, 147-157.

Fourqurean, J.W., Powell, G.V.N., Kenworthy, W.J., Zieman, J.C., 1995. The Effects of Long-Term Manipulation of Nutrient Supply on Competition between the Seagrasses Thalassia testudinum and Halodule wrightii in Florida Bay. Oikos 72, 349. https://doi.org/10.2307/3546120

Grech, A., Chartrand-Miller, K., Erftemeijer, P., Fonseca, M., McKenzie, L., Rasheed, M., Taylor, H., Coles, R., 2012. A comparison of threats, vulnerabilities and management approaches in global seagrass bioregions. Environ. Res. Lett. 7. https://doi.org/10.1088/1748-9326/7/2/024006

Grech, A., Coles, R., Marsh, H., 2011. A broad-scale assessment of the risk to coastal seagrasses from cumulative threats. Mar. Policy 35, 560-567. https://doi.org/10.1016/j.marpol.2011.03.003

Grice, A.M., Loneragan, N.R., Dennison, W.C., 1996. Light intensity and the interactions between physiology, morphology and stable isotopes ratios in five species of seagrass. J. Exp. Mar. Bio. Ecol. 195, 91-110. https://doi.org/10.1016/0022-0981(95)00096-8

Guebert-Bartholo, F.M., Barletta, M., Costa, M.F., Monteiro-Filho, E.L.A., 2011. Using gut contents to assess foraging patterns of juvenile green turtles Chelonia mydas in the Paranagua Estuary, Brazil. Endanger. Species Res. 13, 131-143. https://doi.org/10.3354/esr00320

Hemminga, M.A., 1998. The root/rhizome system of seagrasses: An asset and a burden. J. Sea Res. 39, 183196. https://doi.org/10.1016/S1385-1101(98)00004-5

Hemminga, M.A., Mateo, M.A., 1996. Stable carbon isotopes in seagrasses: Variability in ratios and use in ecological studies. Mar. Ecol. Prog. Ser. 140, 285-298. https://doi.org/10.3354/meps140285

Howard, J., Hoyt, S., Isensee, K., Pidgeon, E., Telszewski, M. (eds. ., 2014. Coastal Blue Carbon: Methods for assessing carbon stocks and emissions factors in mangroves, tidal salt marshes, and seagrass meadows. Arlington, Virginia, USA.

Jennings, S., Reñones, O., Morales-Nin, B., Polunin, N.V.C., Moranta, J., Coll, J., 1997. Spatial variation in 
the $15 \mathrm{~N}$ and13C stable isotope composition of plants, invertebrates and fishes on Mediterranean reefs: Implications for the study of trophic pathways. Mar. Ecol. Prog. Ser. 146, 109-116.

https://doi.org/10.3354/meps146109

Jiang, Z., Huang, X., Zhang, J., 2013. Effect of nitrate enrichment and salinity reduction on the seagrass Thalassia hemprichii previously grown in low light. J. Exp. Mar. Bio. Ecol. 443, 114-122. https://doi.org/10.1016/j.jembe.2013.02.034

Jones, B.L., Cullen-Unsworth, L.C., Unsworth, R.K.F., 2018. Tracking Nitrogen Source Using $\delta 15 N$ Reveals Human and Agricultural Drivers of Seagrass Degradation across the British Isles. Front. Plant Sci. 9, 1-10. https://doi.org/10.3389/fpls.2018.00133

Jones, B.L., Unsworth, R.K.F., 2016. The perilous state of seagrass in the British Isles. R. Soc. open sc 3, 1-14.

Kilminster, K., McMahon, K., Waycott, M., Kendrick, G.A., Scanes, P., McKenzie, L., O’Brien, K.R., Lyons, M., Ferguson, A., Maxwell, P., Glasby, T., Udy, J., 2015. Unravelling complexity in seagrass systems for management: Australia as a microcosm. Sci. Total Environ. 534, 97-109. https://doi.org/10.1016/j.scitotenv.2015.04.061

Krause-jensen, D., Greve, T.M., Nielsen, K., 2005. Eelgrass as a Bioindicator Under the European Water Framework Directive. Water Resour. Manag. 19, 63-75.

Lacey, E.A., Collado-Vides, L., Fourqurean, J.W., 2014. Morphological and physiological responses of seagrasses (Alismatales) to grazers (Testudines: Cheloniidae) and the role of these responses as grazing patch abandonment cues. Rev. Biol. Trop. 62, 1535-1548. https://doi.org/10.15517/rbt.v62i4.12844

Lal, A., Arthur, R., Marbà, N., Lill, A.W.T., Alcoverro, T., 2010. Implications of conserving an ecosystem modifier: Increasing green turtle (Chelonia mydas) densities substantially alters seagrass meadows. Biol. Conserv. 143, 2730-2738. https://doi.org/10.1016/j.biocon.2010.07.020

Lapointe, B.E., Tomasko, D.A., Matzie, W.R., 1994. Eutrophication and trophic state classification of seagrass communities in the Florida Keys. Bull. Mar. Sci. 54, 696-717.

Lee, K.-S., Dunton, K.H., 1997. Effects of in situ light reduction on the maintenance, growth and partitioning of 
carbon resources in Thalassia testudinum Banks ex König. J. Exp. Mar. Bio. Ecol. 53-73.

Lepoint, G., Dauby, P., Gobert, S., 2004. Applications of C and N stable isotopes to ecological and environmental studies in seagrass ecosystems. Mar. Pollut. Bull. 49, 887-891.

https://doi.org/10.1016/j.marpolbul.2004.07.005

Longstaff, B.., Loneragan, N.., O’Donohue, M.., Dennison, W.., 1999. Effects of light deprivation on the survival and recovery of the seagrass Halophila ovalis (R.Br.) Hook. J. Exp. Mar. Bio. Ecol. 234, 1-27. https://doi.org/10.1016/S0022-0981(98)00137-3

Marques, M., da Costa, M.F., Mayorga, M.I.D.O., Pinheiro, P.R., 2004. Water environments: anthropogenic pressures and ecosystem changes in the Atlantic drainage basins of Brazil. Ambio 33, 68-77. https://doi.org/10.1639/0044-7447(2004)033[0068:WEAPAE]2.0.CO;2

McDonald, J.H., 2014. Handbook of Biological Statistics, Third Edit. ed. Sparky House Publishing, Baltimore.

Mckenzie, L., Collier, C., Langlois, L., Yoshida, R., Smith, N., 2016. Marine Monitoring Program. Annual Report for Inshore Seagrass Monitoring: 2014-2015. Report for the Great Barrier Reef Marine Park Authority. Cairns.

McKenzie, L.J., Collier, C.J., Waycott, M., 2011. Reef Rescue Marine Monitoring Program - Inshore Seagrass, Annual Report for the sampling period 1st July 2010-31st May 2011.

McMahon, K., Collier, C.J., Lavery, P.S., 2013. Identifying robust bioindicators of light stress in seagrasses: A meta-analysis. Ecol. Indic. 30, 7-15. https://doi.org/10.1016/j.ecolind.2013.01.030

Mills, V.S., Berkenbusch, K., 2009. Seagrass (Zostera muelleri) patch size and spatial location influence infaunal macroinvertebrate assemblages. Estuar. Coast. Shelf Sci. 81, 123-129. https://doi.org/10.1016/j.ecss.2008.10.005

Nordlund, L.M., Koch, E.W., Barbier, E.B., Creed, J.C., 2016. Seagrass ecosystem services and their variability across genera and geographical regions. PLoS One 11, 1-23. https://doi.org/10.1371/journal.pone.0163091 
Ochieng, C. a., Short, F.T., Walker, D.I., 2010. Photosynthetic and morphological responses of eelgrass (Zostera marina L.) to a gradient of light conditions. J. Exp. Mar. Bio. Ecol. 382, 117-124.

https://doi.org/10.1016/j.jembe.2009.11.007

Oigman-Pszczol, S.S., Creed, J.C., 2011. Can patterns in benthic communities be explained by an environmental pressure index? Mar. Pollut. Bull. 62, 2181-2189. https://doi.org/10.1016/j.marpolbul.2011.07.001

Olesen, B., Enríquez, S., Duarte, C.M., Sand-Jensen, K., 2002. Depth-acclimation of photosynthesis, morphology and demography of Posidonia oceanica and Cymodocea nodosa in the Spanish Mediterranean Sea. Mar. Ecol. Prog. Ser. 236, 89-97. https://doi.org/10.3354/meps236089

Olesen, B., Sand-jensen, K., 1993. Seasonal acclimatization of eelgrass Zostera marina growth to light. Mar. Ecol. Prog. Ser. 94, 91-99.

Orth, R.J., Carruthers, T.J.B., Dennison, W.C., Duarte, C.M., Fourqurean, J.W., Heck Jr, K.L., Hughes, A.R., Kendrick, G.A., Kenworthy, W.J., Olyarnik, S., 2006. A global crisis for seagrass ecosystems. Bioscience 56, 987-996.

Papini, A., Sordo, L., Mosti, S., 2011. Surface interactions of the epiphytic macroalga Hincksia Mitchelliae (Phaeophyceae) with the shoalgrass Halodule wrightii (Cymodoceaceae). J. Phycol. 47, 118-122. https://doi.org/10.1111/j.1529-8817.2010.00935.x

Pitanga, M.E., Montes, M.J.F., Magalhaes, K.M., Reis, T.N. V., 2012. Quantification and classification of the main environmental impacts on a Halodule wrightii seagrass meadow on a tropical island in northeastern Brazil. Ann. Brazilian Acad. Sci. 84, 35-42.

Powell, G.V.N., Kenworthy, W.J., Fourqurean, J.W., 1989. Experimental evidence for nutrient limitation of seagrass growth in a tropical estuary with restricted circulation. Bull. Mar. Sci. 44, 324-340.

R Core Team, 2018. R: A language and environment for statistical computing. Version 3.5.1.

Ralph, P.J., Durako, M.J., Enríquez, S., Collier, C.J., Doblin, M.A., 2007. Impact of light limitation on seagrasses. J. Exp. Mar. Bio. Ecol. 350, 176-193. https://doi.org/10.1016/j.jembe.2007.06.017 
Ralph, P.J., Gademann, R., 2005. Rapid light curves: A powerful tool to assess photosynthetic activity. Aquat. Bot. 82, 222-237. https://doi.org/10.1016/j.aquabot.2005.02.006

Roca, G., Alcoverro, T., Krause-Jensen, D., Balsby, T.J.S., Van Katwijk, M.M., Marbà, N., Santos, R., Arthur, R., Mascaró, O., Fernández-Torquemada, Y., Pérez, M., Duarte, C.M., Romero, J., 2016. Response of seagrass indicators to shifts in environmental stressors: A global review and management synthesis. Ecol. Indic. 63, 310-323. https://doi.org/10.1016/j.ecolind.2015.12.007

Shafer, D.J., 1999. The Effects of Dock Shading on the Seagrass Halodule wrightii in Perdido Bay, Alabama. Estuaries 22, 936. https://doi.org/10.2307/1353073

Short, F.T., Koch, E.W., Creed, J.C., Magalhães, K.M., Fernandez, E., Gaeckle, J.L., 2006. SeagrassNet monitoring across the Americas: Case studies of seagrass decline. Mar. Ecol. 27, 277-289. https://doi.org/10.1111/j.1439-0485.2006.00095.x

Short, F.T., Wyllie-Echeverria, S., 1996. Natural and human-induced disturbance of seagrasses. Environ. Conserv. 23, 17. https://doi.org/10.1017/S0376892900038212

Silva, J., Barrote, I., Costa, M.M., Albano, S., Santos, R., 2013. Physiological responses of Zostera marina and Cymodocea nodosa to light-limitation stress. PLoS One 8, e81058. https://doi.org/10.1371/journal.pone.0081058

Sordo, L., Fournier, J., De Oliveira, V.M., Gern, F., De Castro Panizza, A., Da Cunha Lana, P., 2011. Temporal variations in morphology and biomass of vulnerable Halodule wrightii meadows at their southernmost distribution limit in the southwestern Atlantic. Bot. Mar. 54, 13-21. https://doi.org/10.1515/ВOT.2011.007

Taylor, M., Ravilious, C., Green, E.P., 2003. Mangroves. UNEP WCMC (UNEP World Conservation Monitoring Centre) , Cambridge,.

Tomasko, D.A., Dawes, C.J., Hall, M.O., 1996. The Effects of Anthropogenic Nutrient Enrichment on Turtle Grass (Thalassia testudinum) in Sarasota Bay, Florida. Estuaries 19, 448-456. https://doi.org/10.2307/1352462 
Tomasko, D.A., Lapointe, B.E., 1991. Productivity and biomass of Thalassia testudinum as related to water column nutrient availability and epiphyte levels: field observations and experimental studies. Mar. Ecol. Prog. Ser. 75, 9-17. https://doi.org/10.3354/meps075009

Underwood, A.J., 1997. Experiments in ecology: their logical design and interpretation using analysis of variance, in: Experiments in Ecology: Their Logical Design and Interpretation Using Analysis of Variance. Cambridge University Press.

Unsworth, R.K.F., Collier, C.J., Waycott, M., Mckenzie, L.J., Cullen-unsworth, L.C., 2015. A framework for the resilience of seagrass ecosystems. Mar. Pollut. Bull. 100, 34-46. https://doi.org/10.1016/j.marpolbul.2015.08.016

Waycott, M., Duarte, C.M., Carruthers, T.J.B., Orth, R.J., Dennison, W.C., Olyarnik, S., Calladine, A., Fourqurean, J.W., Heck, K.L., Hughes, A.R., Kendrick, G.A., Kenworthy, W.J., Short, F.T., Williams, S.L., 2009. Accelerating loss of seagrasses across the globe threatens coastal ecosystems. PNAS 1.

Wear, D.J., Sullivan, M.J., Moore, A.D., Millie, D.F., 1999. Effects of water-column enrichment on the production dynamics of three seagrass species and their epiphytic algae. Mar. Ecol. Prog. Ser. 179, 201213. https://doi.org/10.3354/meps179201

Yaakub, S.M., Chen, E., Bouma, T.J., Erftemeijer, P.L.A., Todd, P.A., 2013. Chronic light reduction reduces overall resilience to additional shading stress in the seagrass Halophila ovalis. Mar. Pollut. Bull. https://doi.org/10.1016/j.marpolbul.2013.11.030

Zuur, A.F., leno, E.N., Walker, N., Saveliev, A.A., Smith, G.M., 2009. Mixed effects models and extensions in ecology with R. Springer New York, New York. https://doi.org/10.1007/978-0-387-87458-6 


\section{Appendix}

Table A.1. Table of impact assessment scores attributed to each seagrass site for each perceived impact from 0-3. The impact assessment index is calculated by divided the total score per site by the maximum possible score.

\begin{tabular}{|c|c|c|c|c|c|c|c|c|c|c|c|c|}
\hline Site & Population & Industry & Tourism & $\begin{array}{c}\text { Anchoring/ } \\
\text { boat } \\
\text { activity/ } \\
\text { ports }\end{array}$ & Catchment & Agriculture & $\begin{array}{c}\text { Freshwater } \\
\text { input/ } \\
\text { sewage } \\
\text { outfall } \\
\end{array}$ & Turbidity & $\begin{array}{c}\text { Open-sea } \\
\text { /Lagoon }\end{array}$ & $\begin{array}{c}\text { Evidence } \\
\text { of grazing }\end{array}$ & $\begin{array}{l}\text { Total } \\
\text { score }\end{array}$ & $\begin{array}{c}\text { Impact } \\
\text { assessment } \\
\text { index }\end{array}$ \\
\hline Abraaaozinho & 1 & 1 & 2 & 1 & 1 & 0 & 0 & 0 & 1 & 0 & 7 & 0.233333 \\
\hline Praia do sino & 1 & 0 & 2 & 1 & 1 & 0 & 2 & 1 & 1 & 1 & 9 & 0.333333 \\
\hline Saco du Ceu & 1 & 1 & 1 & 2 & 1 & 0 & 1 & 2 & 3 & 0 & 12 & 0.4 \\
\hline Catita & 1 & 3 & 0 & 1 & 3 & 1 & 0 & 2 & 2 & 0 & 13 & 0.433333 \\
\hline Praia dos Anjos & 2 & 1 & 2 & 3 & 2 & 0 & 0 & 1 & 1 & 2 & 14 & 0.466667 \\
\hline Siriuba & 1 & 0 & 2 & 2 & 1 & 0 & 2 & 3 & 1 & 2 & 14 & 0.466667 \\
\hline Manghuinhos & 2 & 0 & 2 & 2 & 2 & 0 & 1 & 2 & 1 & 3 & 15 & 0.5 \\
\hline Ilha do Japones & 3 & 1 & 2 & 0 & 3 & 0 & 0 & 2 & 3 & 2 & 16 & 0.533333 \\
\hline Ossos & 2 & 0 & 3 & 2 & 2 & 0 & 2 & 1 & 1 & 3 & 16 & 0.533333 \\
\hline Praia Grande & 1 & 3 & 1 & 2 & 3 & 1 & 1 & 3 & 2 & 0 & 17 & 0.566667 \\
\hline
\end{tabular}

Table A.2. Description of epiphyte cover scores used for assessing coverage based on methods developed by Burdick et al. (1993), and described by Cooke \& Paver (2007) for use for determining epiphyte scores in long-term seagrass monitoring programmes.

\begin{tabular}{ccc}
\hline Score & Description & Percentage cover \\
\hline $\mathbf{0}$ & Uninfected leaf & 0 \\
\hline $\mathbf{1}$ & Minimal cover apparent & $0-2$ \\
\hline $\mathbf{2}$ & Up to a quarter of leaf covered & $3-25$ \\
\hline $\mathbf{3}$ & Up to half the leaf covered & $26-50$ \\
\hline $\mathbf{4}$ & Over half of all leaf covered & $51-75$ \\
\hline $\mathbf{5}$ & Almost all of leaf covered & $76-100$ \\
\hline
\end{tabular}


Table A.3. Table of abiotic factors measured at each seagrass site in April 2017. Average light intensity for each site is taken from light recorded within the meadow (middle), \% SI is taken as percentage of surface irradiance reaching meadow edge, measured using Hobo light loggers (in lux).

\begin{tabular}{lllllllll}
\hline Site & $\begin{array}{l}\text { Average } \\
\text { light } \\
\text { intensity } \\
\text { mid- } \\
\text { meadow } \\
\text { (lux) }\end{array}$ & $\begin{array}{l}\text { SD light } \\
\text { intensity }\end{array}$ & $\begin{array}{l}\text { Max light } \\
\text { intensity } \\
\text { during day } \\
\text { (lux) }\end{array}$ & $\begin{array}{l}\text { \% Sl at } \\
\text { deep } \\
\text { edge }\end{array}$ & $\begin{array}{l}\text { Max } \\
\text { temp } \\
\left({ }^{\circ} \mathbf{C}\right)\end{array}$ & $\begin{array}{l}\text { Min } \\
\text { temp } \\
\left({ }^{\circ} \mathbf{C}\right)\end{array}$ & $\begin{array}{l}\text { Secchi } \\
\text { distance } \\
(\mathbf{m})\end{array}$ & $\begin{array}{l}\text { Salinity } \\
(\%)\end{array}$ \\
\hline Abraãozinho & 3835 & 6129 & 34445 & 15.3 & 27.17 & 21.09 & 5.5 & 38 \\
\hline Praia do sino & 3524 & 5562 & 35823 & 13.6 & 26.98 & 25.71 & 3.5 & 34 \\
\hline Saco du Céu & 6692 & 14608 & 220446 & 23.7 & 29.65 & 23.87 & 2.5 & 36 \\
\hline Catita & 5280 & 13379 & 198401 & 11.9 & 33.43 & 26.68 & 2.5 & 32 \\
\hline $\begin{array}{l}\text { Praia dos } \\
\text { Anjos }\end{array}$ & 3651 & 5046 & 24800 & 13.2 & 24.84 & 22.24 & 5 & 37 \\
\hline Siriuba & 1409 & 2231 & 12400 & 6.7 & 26.59 & 25.61 & 0.75 & 35 \\
\hline Manghuinhos & 3815 & 6550 & 126756 & 13.8 & 26.88 & 23.77 & 2.5 & 39 \\
\hline $\begin{array}{l}\text { Ilha do } \\
\text { Japonês }\end{array}$ & 6555 & 10472 & 170846 & 36.2 & 32.09 & 21.19 & 3 & 39 \\
\hline Ossos & 5522 & 8202 & 52356 & 11.7 & 26 & 23.97 & 3.75 & 39 \\
\hline Praia Grande & 2204 & 7541 & 187379 & 14.0 & 33.43 & 26.10 & 0.5 & 35 \\
\hline
\end{tabular}

Table A.4. Results from Analysis of variance with shoot, meadow and photo-physiological responses to impact index and site included as random factor.

\begin{tabular}{llccc}
\hline Width & & Df & F-value & Pr(>F) \\
\hline Ave.leaf.length & Impact score & 2 & 91.42 & $<0.001$ \\
\hline Epiphyte & Impact score & 2 & 14.74 & $<0.001$ \\
\hline Shoot density & as.factor (Site) & 7 & 48.56 & $<0.001$ \\
\hline & Impact score & 2 & 3.52 & 0.03 \\
\hline Dry weight & as.factor (Site) & 7 & 13.42 & $<0.001$ \\
\hline & Impact score & 2 & 66.51 & $<0.001$ \\
\hline Alpha & as.factor (Site) & 7 & 43.62 & $<0.001$ \\
\hline & Impact score & 2 & 50.08 & $<0.001$ \\
\hline ETRmax & as.factor (Site) & 7 & 36.99 & $<0.001$ \\
\hline & Impact score & 2 & 1.32 & 0.278 \\
\hline
\end{tabular}




\begin{tabular}{llccc}
\hline Ek & Impact score & 2 & 2.77 & 0.072 \\
\hline & as.factor (Site) & 7 & 17.27 & $<0.001$ \\
\hline
\end{tabular}

Table A.5. Results from the post-hoc Tukey HSD pairwise comparison test for each variable measured.

\begin{tabular}{|c|c|c|c|c|}
\hline Width & diff & Iwr & upr & $p$ adj \\
\hline low-med-high & -0.01120476 & -0.03842546 & 0.016016 & 0.598286 \\
\hline med-high-high & 0.11367441 & 0.08931648 & 0.138032 & 0 \\
\hline med-high-low-med & 0.12487917 & 0.09965718 & 0.150101 & 0 \\
\hline \multicolumn{5}{|l|}{ Ave leaf length } \\
\hline low-med-high & -1.347614 & -3.918443 & 1.223215 & 0.435291 \\
\hline med-high-high & 3.770645 & 1.470187 & 6.071104 & 0.000377 \\
\hline med-high-low-med & 5.118259 & 2.736196 & 7.500322 & 1.7E-06 \\
\hline \multicolumn{5}{|l|}{ Epiphyte } \\
\hline low-med-high & -0.21339175 & -0.40533217 & -0.02145 & 0.024946 \\
\hline med-high-high & -0.13007459 & -0.30162185 & 0.041473 & 0.176817 \\
\hline med-high-low-med & 0.08331716 & -0.09456508 & 0.261199 & 0.514472 \\
\hline \multicolumn{5}{|l|}{ Shoot density } \\
\hline low-med-high & -51.38889 & -62.348165 & -40.4296 & 0 \\
\hline med-high-high & -33.5 & -43.751464 & -23.2485 & 0 \\
\hline med-high-low-med & 17.88889 & 7.637425 & 28.14035 & 0.000303 \\
\hline \multicolumn{5}{|l|}{ Dry weight } \\
\hline low-med-high & -0.311016667 & -0.39909479 & -0.22294 & 0 \\
\hline med-high-high & -0.004573611 & -0.08696315 & 0.077816 & 0.990139 \\
\hline med-high-low-med & 0.306443056 & 0.22405352 & 0.388833 & 0 \\
\hline \multicolumn{5}{|l|}{ Alpha } \\
\hline low-med-high & 0.018111111 & -0.01028242 & 0.046505 & 0.280933 \\
\hline med-high-high & 0.013763889 & -0.01279583 & 0.040324 & 0.428903 \\
\hline med-high-low-med & -0.004347222 & -0.03090694 & 0.022213 & 0.917598 \\
\hline \multicolumn{5}{|l|}{ ETRmax } \\
\hline low-med-high & 49.65061 & 19.47277 & 79.82845 & 0.000655 \\
\hline med-high-high & 12.95864 & -15.27015 & 41.18743 & 0.513189 \\
\hline med-high-low-med & -36.69197 & -64.92076 & -8.46319 & 0.007855 \\
\hline \multicolumn{5}{|l|}{ Ek } \\
\hline low-med-high & 76.99044 & -29.48394 & 183.4648 & 0.198266 \\
\hline med-high-high & -16.52768 & -116.12534 & 83.06998 & 0.915404 \\
\hline med-high-low-med & -93.51813 & -193.11579 & 6.079538 & 0.069808 \\
\hline
\end{tabular}


Table A.6. Table to show results of Principal Component Analysis of shoot scale data (PCA1) and meadow-scale data (PCA2).

\begin{tabular}{lll}
\hline PCA1 & PC1 & PC2 \\
\hline Summary Values & & \\
\hline Eigenvalues & $\mathbf{1 . 4 5}$ & $\mathbf{0 . 9 2 2}$ \\
\hline Percent variation & 48.3 & 30.7 \\
\hline Cumulative percent variation & 48.3 & 79.0 \\
\hline Seagrass variables & & \\
\hline Leaf length & $\mathbf{0 . 4 2 2}$ & $\mathbf{0 . 8 7 6}$ \\
\hline Leaf width & $-\mathbf{0 . 6 6 8}$ & 0.127 \\
\hline Epiphyte & $-\mathbf{0 . 6 1 3}$ & $\mathbf{0 . 4 6 4}$ \\
\hline & & \\
\hline PCA2 & & \\
\hline Summary Values & PC1 & PC2 \\
\hline Eigenvalues & $\mathbf{2 . 4 4}$ & $\mathbf{1 . 4 1}$ \\
\hline Percent variation & 48.8 & 28.2 \\
\hline Cumulative percent variation & 48.8 & 77.0 \\
\hline Seagrass variables & & \\
\hline Shoot density & $-\mathbf{0 . 4 3 4}$ & -0.513 \\
\hline Dry weight & $-\mathbf{0 . 5 0 4}$ & -0.319 \\
\hline Alpha & $\mathbf{0 . 3 4 8}$ & 0.246 \\
\hline ETRmax & $-\mathbf{0 . 3 9 0}$ & $\mathbf{0 . 6 3 2}$ \\
\hline Ek & $-\mathbf{0 . 5 3 4}$ & $\mathbf{0 . 4 1 8}$ \\
\hline & & \\
\hline & & \\
\hline
\end{tabular}

Table A.7. Results from the generalised additive models used to describe shoot density. Models 1-4 showed the best fit by way of deviance explained and $R^{2}$ value.

\begin{tabular}{lcccc}
\hline \multicolumn{5}{l}{ Model 1 = gam(shoot_density as.factor(Impact_cat) + Alpha + leaf length + N15) } \\
\hline & Estimate & Std. Error & t-value & p-value \\
\hline (Intercept) & 12.065 & 1.142 & 10.563 & $0.0005^{* * *}$ \\
\hline Impact med-high & -0.226 & 0.366 & -0.619 & 0.570 \\
\hline Impact high & -0.338 & 0.427 & -0.790 & 0.474 \\
\hline Alpha & -11.925 & 3.934 & -3.031 & $0.039^{*}$ \\
\hline Leaf length & -0.093 & 0.015 & -6.234 & $0.003^{* *}$ \\
\hline$\delta N^{15}$ & 0.659 & 0.114 & 5.765 & $0.004^{* *}$ \\
\hline R-sq. (adj) = 0.978, deviance explained = 96.5\%, GVC=1054.1 & & \\
\hline Model 2 = gam(shoot_density as.factor(Impact_cat) + leaf length + N15) \\
\hline (Intercept) & 8.914 & 0.626 & 14.238 & $3.08 \mathrm{e}-05^{* * *}$ \\
\hline Impact med-high & 0.166 & 0.547 & 0.304 & 0.773 \\
\hline Impact high & 0.285 & 0.618 & 0.462 & 0.664 \\
\hline Leaf length & -0.104 & 0.022 & -4.654 & $0.006^{* *}$ \\
\hline
\end{tabular}




\begin{tabular}{|c|c|c|c|c|}
\hline$\delta N^{15}$ & 0.445 & 0.137 & 3.255 & $0.023 *$ \\
\hline \multicolumn{5}{|c|}{ R-sq. $($ adj $)=0.918$, deviance explained $=89.1 \%, G V C=2104.6$} \\
\hline \multicolumn{5}{|c|}{$\begin{array}{l}\text { Model } 3 \text { = gam(shoot_density as.factor(Impact_cat) + s(Alpha) + s(leaf length)+ } \\
\text { F(Site) }\end{array}$} \\
\hline (Intercept) & 7.001 & 0.211 & 33.169 & $<2 \mathrm{e}-16^{* * *}$ \\
\hline Impact med-high & 0.243 & 0.235 & 5.296 & $3.02 \mathrm{e}-06 * * *$ \\
\hline Impact high & 1.953 & 0.255 & 7.660 & $7.85 \mathrm{e}-10 * * *$ \\
\hline \multicolumn{2}{|c|}{ Significance of smooth terms } & Ref.df & F-value & p-value \\
\hline s(Leaf length) & edf & 8.957 & 7.756 & $1.56 \mathrm{e}-07^{* * *}$ \\
\hline s(Alpha) & 1.00 & 1.00 & 0.581 & 0.450 \\
\hline$s($ Site) & 8.64 & 1.00 & 0.000 & 0.539 \\
\hline \multicolumn{5}{|c|}{ R-sq. $($ adj $)=0.794$, deviance explained $=79.5 \%, G V C=1410.3$} \\
\hline \multicolumn{5}{|c|}{ Model 4 = gam(shoot_density as.factor(Impact_cat) + s(leaf length)+F(Site) } \\
\hline (Intercept) & 7.056 & 0.198 & 35.737 & $<2 \mathrm{e}-16 * * *$ \\
\hline Impact med-high & 1.180 & 0.219 & 5.385 & $2.11 \mathrm{e}-06 * * *$ \\
\hline Impact high & 1.857 & 0.221 & 8.393 & $5.33 \mathrm{e}-11 * * *$ \\
\hline Significance of smooth & edf & Ref.df & F-value & $p$-value \\
\hline s(Leaf length) & 8.64 & 8.957 & 7.756 & $8.01 \mathrm{e}-08^{* * *}$ \\
\hline s(Site) & $6.256 e-06$ & 1.00 & 0.000 & 0.822 \\
\hline \multicolumn{5}{|c|}{ R-sq. $($ adj $)=0.794$, deviance explained $=79.2 \%, G V C=1374.6$} \\
\hline \multicolumn{5}{|c|}{ Model 5 = gam(shoot_density s(Alpha) + s(leaf length)+F(Site) } \\
\hline (Intercept) & 7.046 & 0.220 & 31.98 & $<2 \mathrm{e}-16^{* * *}$ \\
\hline Significance of smooth & edf & Ref.df & F-value & p-value \\
\hline S(Alpha) & 1.000 & 1.000 & 0.327 & 0.57 \\
\hline s(Leaf length) & 1.000 & 1.000 & 32.687 & $3.12 \mathrm{e}-07^{* * *}$ \\
\hline$s($ Site) & 0.976 & 1.000 & 46.213 & $2.06 \mathrm{e}-09 * * *$ \\
\hline \multicolumn{5}{|c|}{ R-sq. $($ adj $)=0.634$, deviance explained $=61.9 \%, G V C=1874.8$} \\
\hline
\end{tabular}

